\title{
Effects of previous field-exposure history on the uptake of trace metals from water and food by the barnacle Balanus amphitrite
}

\author{
Philip S. Rainbow ${ }^{1, *}$, Graham Blackmore ${ }^{2}$, Wen-Xiong Wang ${ }^{2}$ \\ ${ }^{1}$ Department of Zoology, The Natural History Museum, Cromwell Road, London SW7 5BD, UK \\ ${ }^{2}$ Department of Biology, The Hong Kong University of Science and Technology (HKUST), Clear Water Bay, \\ Kowloon, Hong Kong SAR
}

\begin{abstract}
Rates of uptake from solution and assimilation efficiencies of trace metals were investigated in populations of the barnacle Balanus amphitrite with different metal contamination histories in Hong Kong coastal waters. The hypothesis under examination was that differential metal preexposure in the field would affect the assimilation efficiency (AE) of that metal and its rate of uptake from solution. There were no significant differences between the AE of $\mathrm{Ag}, \mathrm{Cd}$, and $\mathrm{Zn}$ of the different populations under the same experimental conditions, showing that previous field contamination history had no effect on the assimilation of the 3 trace metals examined. On the other hand, dissolved $\mathrm{Cd}$ and $\mathrm{Zn}$ uptake-rate constants did vary significantly between populations under the same experimental conditions, but for neither metal was there a significant correlation between metal uptake rate from solution and accumulated metal concentration, which is a surrogate measure of previous contaminant history. Thus, previous field-exposure history had no significant effect on the subsequent uptake of $\mathrm{Zn}$ or $\mathrm{Cd}$ from solution. Efflux-rate constants of accumulated $\mathrm{Ag}, \mathrm{Cd}$, and $\mathrm{Zn}$ in the barnacle are low in comparison to those of other benthic invertebrates, in a possible correlation with the large percentage of metal incorporated in insoluble form. A change in salinity from 33 to 15 caused an increase in the dissolved uptake of $\mathrm{Zn}$ and $\mathrm{Cd}$ in barnacles collected from a fully saline site, expected from physicochemical changes in the complexation of free $\mathrm{Zn}$ and $\mathrm{Cd}$ ions by chloride. The same salinity change caused an increase in dissolved $\mathrm{Cd}$ (but not $\mathrm{Zn}$ ) uptake in barnacles from a low salinity site, suggesting some physiological acclimation. $\mathrm{AE}$ of $\mathrm{Ag}, \mathrm{Cd}$, and $\mathrm{Zn}$ did not differ at salinities of 15 and 33 in barnacles from the low salinity site. Increased exposure to metals in the laboratory or in extreme field conditions may nevertheless bring about changes in metal uptake rates in coastal invertebrates.
\end{abstract}

KEY WORDS: Trace metals $\cdot$ Barnacle $\cdot$ Balanus amphitrite $\cdot \mathrm{Ag} \cdot \mathrm{Cd} \cdot \mathrm{Zn} \cdot$ Uptake-rate constant Assimilation efficiency $\cdot$ Efflux-rate constant $\cdot$ Salinity

\section{INTRODUCTION}

Marine invertebrates take up trace metals from both water and food. Subsequent accumulation of these metals follows patterns that vary between invertebrate taxa (Rainbow 2002). Interest in the metal bioaccumulation processes of marine invertebrate stems from their use as biomonitors of contaminant availability (Phillips \& Rainbow 1994), and more recently from the development of models to explain field metal concentrations and to allow delineation of pathways involved in the biogeochemical cycling of trace metals (Wang \& Fisher 1999a,b, Rainbow \& Wang 2001, Wang 2002), not least because all trace metals have the potential to generate ecotoxicological effects (Phillips \& Rainbow 1994).

One factor that may affect the uptake of a trace metal is a history of previous exposure to that metal. For ex- 
ample, metal exposure might induce physiological processes of detoxificatory metal binding that could arguably affect uptake processes (Blackmore \& Wang 2002). Furthermore, if pre-exposure involved metal bioavailabilities causing high trace metal uptake-rates of ecotoxicological significance, there might be a selection pressure to reduce uptake in the pre-exposed populations (Rainbow et al. 1999). Ultimately, such selection pressure will lead to the presence of metal tolerant populations (Luoma 1977). Tolerance may not necessarily be brought about by changes in uptake-rate alone, but by changes in rates of excretion and/or storage detoxification (Mason \& Jenkins 1995). For example, the copper-tolerant population of the polychaete worm Nereis diversicolor from the severely contaminated Restronguet Creek in Cornwall, England, actually has an atypically high rate of copper accumulation, but an associated high rate of copper detoxification (Bryan \& Hummerstone 1971, Bryan 1974, 1976).

Rainbow et al. (1999) measured trace metal uptake from solution in crabs and amphipod crustaceans collected from coastal sites differentially enriched with trace metals; mean metal uptake-rates in fact did not show consistent significant differences between metalrich and control sites, indicating that metal exposures had not been sufficient to select for a reduction in dissolved metal uptake-rates in the populations from the more contaminated sites. Therefore, existing physiological detoxification mechanisms in the crustaceans sufficed to cope with the extra uptake of metal in the metal-rich sites (Nassiri et al. 2000).

Blackmore \& Wang (2002) considered both uptake from solution and assimilation efficiencies in their study of the effect of metal pre-exposure on uptakerates of $\mathrm{Cd}$ and $\mathrm{Zn}$ by the green mussel Perna viridis. In this case $\mathrm{Cd}$ assimilation (but not $\mathrm{Cd}$ uptake from solution) was increased substantially by pre-exposure to $\mathrm{Cd}$, in correlation with an increase in Cd tissue burden and the association of $\mathrm{Cd}$ with metallothioneinlike proteins (MTLP) in the mussels; on the other hand, neither $\mathrm{Zn}$ assimilation nor $\mathrm{Zn}$ uptake from solution was significantly affected by pre-exposure to $\mathrm{Zn}$ (Blackmore \& Wang 2002). Shi et al. (2003) showed increased assimilation of Ag by $P$. viridis after long preexposure of the mussels to Ag, in correlation with the possible binding of Ag by sulphide. Blackmore and Wang (unpubl.) have investigated further the possible role of metallothionein (MT) in trace metal uptake by a gastropod mollusc (the dogwhelk Thais clavigera). The assimilation of $\mathrm{Cd}$ and $\mathrm{Hg}$ (but not $\mathrm{Zn}$ ) was significantly increased in dogwhelks with higher MT concentrations, both in field populations and following MT induction by laboratory exposure to $\mathrm{Cd}$. uptake-rates from solution were unaffected by MT body concentrations.
Therefore, trace metal assimilation efficiencies in marine invertebrates may be affected by metal preexposure, perhaps in correlation with the induction of MT or sulphide for detoxificatory binding, while rates of uptake from solution seem unaffected by previous exposure history. In this study, the hypothesis is tested that differential metal pre-exposure in the field affects the assimilation efficiency of that metal and its rate of uptake from solution. The marine invertebrate investigated is the barnacle Balanus amphitrite in an ideal field environment, the coastal waters of Hong Kong, with well explored geographical differences in trace metal bioavailabilities to barnacles (Rainbow \& Blackmore 2001). Barnacles, particularly B. amphitrite, are ideal test invertebrates for this purpose, because their metal accumulation patterns are well understood (see Rainbow 1998), their assimilation efficiencies readily measured (Wang \& Rainbow 2000, Rainbow \& Wang 2001), and their accumulated metal concentrations are themselves integrated records of their previous metal exposure histories (Phillips \& Rainbow 1988, Rainbow \& Blackmore 2001). In addition, B. amphitrite is a suitable model organism for the necessary experiments (Wang et al. 1999a,b).

One specific question is addressed: Do the previous field-exposure histories of barnacle populations correlate with any observed differences in trace metal uptake-rates from solution or assimilation efficiencies? Collection sites with differing trace metal bioavailabilities to Balanus amphitrite (Rainbow \& Blackmore 2001) were selected across the coastal waters of Hong Kong. In the laboratory, measurements were made of the uptake-rates of $\mathrm{Cd}$ and $\mathrm{Zn}$ from solution, and of the assimilation efficiencies of $\mathrm{Ag}, \mathrm{Cd}$ and $\mathrm{Zn}$ by the barnacles from a standard food prey, the diatom Thalassiosira weissflogii, for correlation against body concentrations of field collected specimens from each population. Also measured were the metal efflux-rates of the different populations, and a preliminary assessment was made of the distribution of accumulated metal concentrations into soluble and insoluble components to compare detoxificatory processes used by the different barnacles. The most western site (Tai $\mathrm{O}_{\text {; }}$ see Fig. 1) has a lower ambient salinity than the other fully marine sites, and therefore measurements were made at 2 salinities (15 and 33) for the Tai O population, matched by equivalent measurements at 2 salinities for the population from the most eastern site with high salinity (Wong Shek).

\section{MATERIALS AND METHODS}

Collection sites. The barnacle Balanus amphitrite was collected from 5 sites in Hong Kong coastal 
waters (Fig. 1) on 8 to 10 August 2002, and held in the laboratory in filtered $(0.2 \mu \mathrm{m})$ seawater at $23^{\circ} \mathrm{C}$ and 33 salinity (15 for Tai $\mathrm{O}$ barnacles) for up to $7 \mathrm{~d}$ before the start of experiments. Individual barnacles were isolated on small pieces of mussel Perna viridis or oyster Saccostrea cucullata shell for all experiments, carried out at $23^{\circ} \mathrm{C}$ in filtered seawater.

Of the 5 sites depicted in Fig. 1, 3 (the central sites of Tsing Yi, Aberdeen and Kowloon City) are potentially metal-contaminated from local industrial activity. Tai $\mathrm{O}$ in the west is under the effect of the Pearl River Estuary, causing reduced salinity and providing some contaminant metal load from upriver in Guangdong Province, Southern China (Phillips \& Rainbow 1988, Rainbow \& Blackmore 2001). Low salinity may well cause raised bioavailabilities of certain dissolved metals such as $\mathrm{Cd}$ and $\mathrm{Zn}$ by increasing the availability of the free metal ion in circumstances of reduced chloride complexation (Phillips \& Rainbow 1994, Rainbow 1995a, 1997), even in the absence of raised total dissolved metal concentrations. It is expected, therefore, that barnacles from Tai $\mathrm{O}$ may show some evidence of exposure to higher background trace metal bioavailabilities. Wong Shek in the east is a fully marine site lacking sources of local metal contamination, and is considered to be a 'control' site.

Radiotracers. Radioisotopes ${ }^{110 \mathrm{~m}} \mathrm{Ag}$ (half-life: $t_{1 / 2}=$ $249.8 \mathrm{~d}),{ }^{109} \mathrm{Cd}\left(t_{1 / 2}=462 \mathrm{~d}\right)$ and ${ }^{65} \mathrm{Zn}\left(t_{1 / 2}=244 \mathrm{~d}\right)$ were obtained from New England Nuclear, Boston, MA, USA, or Riso National Laboratory, Denmark.

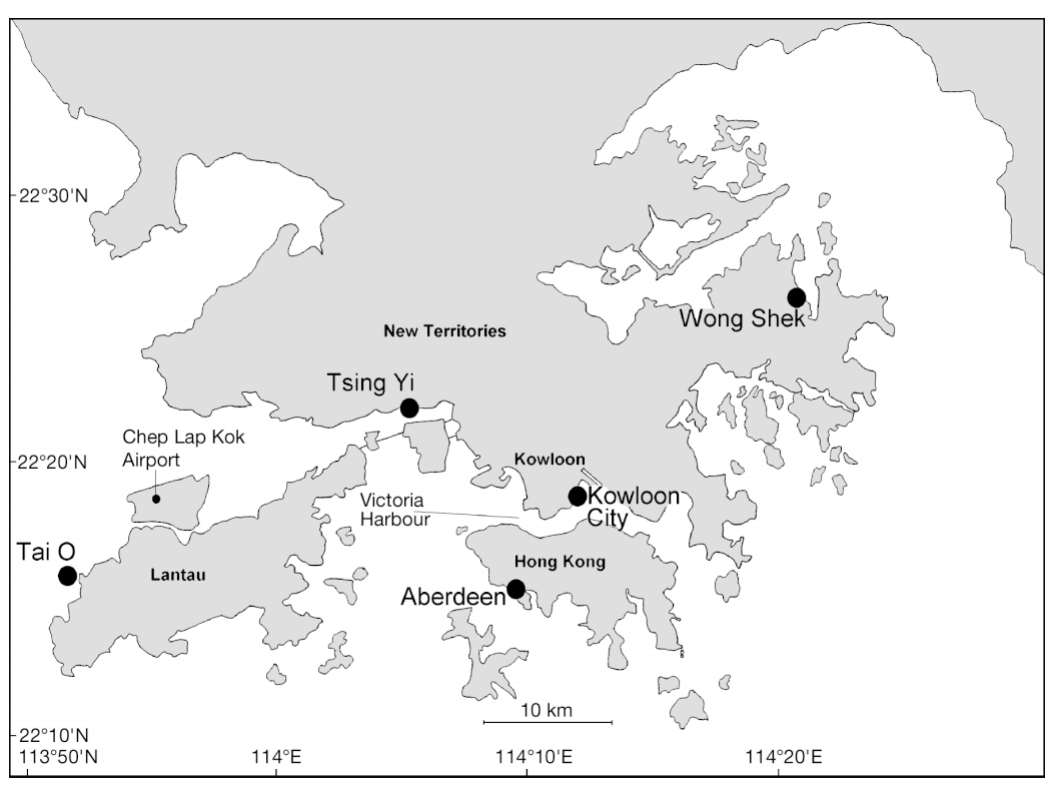

Fig. 1. Map of Hong Kong coastal waters showing the locations of the 5 sites from which each population of Balanus amphitrite was collected
Radioisotopes in individual live barnacles, dissected barnacle parts, faecal pellets and water samples were counted on a Wallac gamma counter. Spillover of radioisotopes was corrected for, and all counts were related to standards for each isotope and corrected for radioactive decay. The gamma emissions of ${ }^{110 \mathrm{~m}} \mathrm{Ag}$ were determined at $658 \mathrm{keV},{ }^{109} \mathrm{Cd}$ at 88 $\mathrm{keV}$, and ${ }^{65} \mathrm{Zn}$ at $1115 \mathrm{keV}$, and counting times adjusted so that the propagated counting errors were typically $<5 \%$.

Uptake from solution. All 5 populations were exposed in groups to each of 4 radioactively labelled dissolved concentrations of $\mathrm{Ag}, \mathrm{Cd}$ and $\mathrm{Zn}$ at a salinity of 33. A selection of barnacles from the Tai O population held at a salinity of 15 were therefore transferred to 33 salinity over $3 \mathrm{~d}$ and held for a further $2 \mathrm{~d}$ at 33. A subgroup of the Wong Shek barnacles was transferred from salinities of 33 to 15 over the same time period. There were thus 7 experimental populations: barnacles from all 5 sites at 33, and barnacles from Tai $\mathrm{O}$ and Wong Shek at 15. The dissolved concentrations chosen were $0.05,0.1,0.5$ and $2 \mu \mathrm{g} \mathrm{Ag} \mathrm{l^{-1 }}, 0.5,2,10$ and

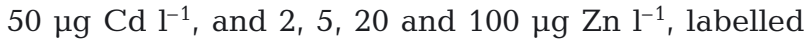
with $0.1 \mu \mathrm{Ci}{ }^{110 m} \mathrm{Ag} \mathrm{l}^{-1}, 0.5 \mu \mathrm{Ci}{ }^{109} \mathrm{Cd} \mathrm{l}^{-1}$ and $1 \mu \mathrm{Ci}$ ${ }^{65} \mathrm{Zn} \mathrm{l^{-1 }}$ respectively. These dissolved concentrations represent elevated but environmentally realistic concentrations in metal-contaminated coastal waters. The 3 lowest metal concentrations were combined, as were the other 3 concentrations in ascending order, giving 4 exposure treatments in total for each of the 7 experimental populations. It was necessary to combine exposure concentrations in this way in order to keep the number of experimental populations of barnacles in manageable proportions. All experimental beakers were soaked in the appropriate experimental solution for $1 \mathrm{~d}$ before experiments in order to saturate all adsorption sites in the beakers. Water samples were counted regularly from representative experimental beakers, confirming that there was no significant loss of labelled metal during experiments. Five barnacles were taken from each exposure treatment for each experimental population after 2, 4, 8 and $24 \mathrm{~h}$, rinsed with filtered seawater and frozen at $-20^{\circ} \mathrm{C}$ before the individual bodies were dissected out, counted wet in the gamma counter, dried individually at $60^{\circ} \mathrm{C}$ on preweighed aluminium foil trays, and weighed.

Assimilation efficiencies. The assimilation efficiencies (AE) of $\mathrm{Ag}, \mathrm{Cd}$ and 
Zn were determined in barnacles feeding on the diatom Thalassiosira weissflogii (CCMP 1048) obtained from the Provasoli-Guillard Phytoplankton Collection Center, West Southbay Harbor, ME, USA, and maintained in f/2 medium (Guillard \& Ryther 1962) at $18^{\circ} \mathrm{C}$ and a light illumination of $100 \mu \mathrm{mol} \mathrm{m}{ }^{-2}$ $\mathrm{s}^{-1}$ with a 14:10 h light:dark cycle. The phytoplankton was radiolabelled as described in Wang \& Rainbow (2000). Briefly, the cells were removed from their culture, filtered and resuspended in $50 \mathrm{ml} 0.2 \mu \mathrm{m}$ filtered seawater enriched with $\mathrm{f} / 2$ levels of $\mathrm{N}, \mathrm{P}, \mathrm{Si}$, vitamins, and $\mathrm{f} / 20$ levels of trace metals minus EDTA, $\mathrm{Cu}$, and Zn (Guillard \& Ryther 1962). Each radioisotope was added at $555 \mathrm{kBq} \mathrm{l}^{-1}$ (corresponding to $4.7 \mathrm{nM}$ for ${ }^{110 \mathrm{~m}} \mathrm{Ag}, 6.7 \mathrm{nM}$ for ${ }^{109} \mathrm{Cd}$ and $80 \mathrm{pM}$ for $\left.{ }^{65} \mathrm{Zn}\right)$. The phytoplankton were grown for $3 \mathrm{~d}$, allowing the cells to be uniformly radiolabelled, after which the cells were filtered from the radioactive medium and rinsed with filtered seawater before being fed to the barnacles.

The AE of metals were determined with a pulsechase feeding technique as described in Wang \& Fisher (1999b) and Wang \& Rainbow (2000). Barnacles were placed in $100 \mathrm{ml}$ filtered seawater and fed on radiolabelled food particles at a diatom cell density of ca. $2.2 \mathrm{mg} \mathrm{l}^{-1}$. After 30 to $45 \mathrm{~min}$ feeding, before egestion of radioactive faeces, individual barnacles were rinsed with non-radiolabelled water and their radioactivity was counted. Five replicate individuals from each treatment population were then placed individually in beakers containing $100 \mathrm{ml}$ filtered seawater with unlabelled Thalassiosira weissflogii to promote depuration of ingested radiolabelled food. Faeces produced by the barnacles were removed at frequent time intervals and their radioactivity analyzed. The radioactivity remaining in the barnacles was measured over a period of $48 \mathrm{~h}$. Water and food were renewed in the individual experimental beakers on each occasion when the radioactivity in the barnacle was counted. Because there was negligible egestion of unassimilated metals in faeces following $24 \mathrm{~h}$ of depuration, the AE was defined as the percentage of ingested radioisotope retained in the barnacles following $24 \mathrm{~h}$ of depuration, consistent with the approach of Wang \& Rainbow (2000) for the barnacle Balanus trigonus.

Experiments were carried out with the groups of barnacles from all 5 sites at a salinity of 33, and from Wong Shek and Tai $\mathrm{O}$ also at 15.

Efflux-rate measurements. Thalassiosira weissflogii, radiolabelled as above, were fed to a further 25 barnacles from each of the same treatment populations as for AE measurements. The barnacles were allowed to feed on the radiolabelled diatoms for a total of $30 \mathrm{~h}$ over $6 \mathrm{~d}$ (i.e. $5 \mathrm{~h} \mathrm{~d}^{-1}$ ). In the intervening periods the barnacles were emersed for brief periods $(2 \mathrm{~h})$ daily and fed unlabelled T. weissflogii. At the end of the $6 \mathrm{~d}$, the 25 barnacles from each treatment were counted live and the 10 with the highest counts were selected for efflux-rate measurements. These were fed unlabelled T. weissflogii for another $30 \mathrm{~d}$, and counted at intervals over this period.

All 25 barnacles from each treatment (15 barnacles after 6 d radiolabelled feeding, plus 10 fed unlabelled diatoms for a further $30 \mathrm{~d}$ ) were frozen at $-80{ }^{\circ} \mathrm{C}$ for analyses of the fractionation of accumulated labelled metals (see below).

Fractionation of accumulated metals. The subcellular ${ }^{110 \mathrm{~m}} \mathrm{Ag},{ }^{109} \mathrm{Cd}$ and ${ }^{65} \mathrm{Zn}$ distributions in barnacle bodies following feeding upon radiolabelled Thalassiosira weissflogii over $6 \mathrm{~d}$ and after $30 \mathrm{~d}$ depuration (see above) were determined by subjecting the bodies to a differential centrifugation and tissue digestion procedures, using a modified method of Wallace et al. (1998). Barnacles were pooled into groups of 5 bodies and homogenised in $1 \mathrm{ml}$ of distilled water, and the homogenate centrifuged at $1450 \times g$ for $15 \mathrm{~min}$ at $4{ }^{\circ} \mathrm{C}$. The pellet contained tissue fragments and cellular debris. The $1450 \times g$ supernatants were further fractionated at $100000 \times g$ for $1 \mathrm{~h}$ at $4{ }^{\circ} \mathrm{C}$ to produce an intracellular pellet containing nuclear, mitochondrial and microsomal fractions. The $1450 \times g$ and $100000 \times g$ pellets were combined to form the insoluble fraction.

The $100000 \times g$ supernatants contained the cytosol with proteins and were fractionated following heat treatment $\left(80^{\circ} \mathrm{C}\right.$ for $10 \mathrm{~min}$, then ice cooling for $\left.1 \mathrm{~h}\right)$ and centrifugation at $50000 \times g\left(10 \mathrm{~min}\right.$ at $\left.4^{\circ} \mathrm{C}\right)$. This separated the heat-stable metallothionein-like proteins (MTLP), which remained in the supernatant, from other (heat-sensitive) proteins that were denatured by heat treatment and, therefore, formed the pellet.

This differential centrifugation and heat treatment resulted in 3 fractions: an insoluble fraction, and 2 soluble components - MTLPs and other (heat-sensitive) proteins. All fractions were radioassayed for ${ }^{110 \mathrm{~m}} \mathrm{Ag}$, ${ }^{109} \mathrm{Cd}$ and ${ }^{65} \mathrm{Zn}$ to allow estimation of the subcellular distribution of these metals.

Field concentrations. Another 100 barnacles from each site at the time of collection were frozen at $-80^{\circ} \mathrm{C}$ before dissection of individual bodies, for measurement of total body-accumulated $\mathrm{Ag}, \mathrm{Cd}, \mathrm{Cr}, \mathrm{Cu}$ and Zn concentrations by ICP-MS (Elan 6000, Perkin Elmer). Bodies were pooled into 10 groups of 10 samples, dried to constant weight at $60^{\circ} \mathrm{C}$, digested in concentrated nitric acid and made up to $5 \mathrm{ml}$ for analysis. Random checks were made throughout the analyses using aliquots of a certified reference material (Standard Reference Material 1566a Oyster tissue, US Department of Commerce, Technology Administration, National Institute of Standards and Technology, Gaitherburg, MD, USA) and agreement was within $10 \%$. 
In order to allow for the possible effects of any size differences between populations, accumulated concentrations are quoted as weight-adjusted means derived from best-fit linear regressions of logged concentration (y) against logged individual body dry weight (see Rainbow \& Blackmore 2001). Weight-adjusted means are the estimated metal concentrations in barnacle bodies of the mean dry weight of all individual barnacle bodies included in the analysis. Metal concentrations are compared by ANCOVA of these double logged regressions.

\section{RESULTS}

Uptake from solution. The uptake of labelled $\mathrm{Cd}$ and Zn from solution into the bodies of the barnacles was linear over time at each exposure concentration, as depicted for $\mathrm{Cd}$ uptake by barnacles from Tsing $\mathrm{Yi}$ (Fig. 2). Table 1 provides details of the best-fit leastsquares linear regressions for dissolved $\mathrm{Cd}$ and $\mathrm{Zn}$ uptake for each treatment population, confirming a significant fit in 53 of the 56 cases. The slope of these regression lines is the uptake-rate of new labelled metal (ng g ${ }^{-1} \mathrm{~h}^{-1}$ ). The intercept of these lines can be interpreted as the radiolabelled metal (ng $\mathrm{g}^{-1}$ ) adsorbed onto the surface of the barnacle body, as opposed to new metal absorbed into the body (see White \& Rainbow 1984).

Since uptake is linear at each exposure, it is possible to transform each accumulated concentration ( $\mathrm{ng} \mathrm{g}^{-1}$ ) into an uptake-rate $\left(\mathrm{ng} \mathrm{g}^{-1} \mathrm{~h}^{-1}\right)$ by dividing by the time of exposure (h). A further refinement is to subtract the

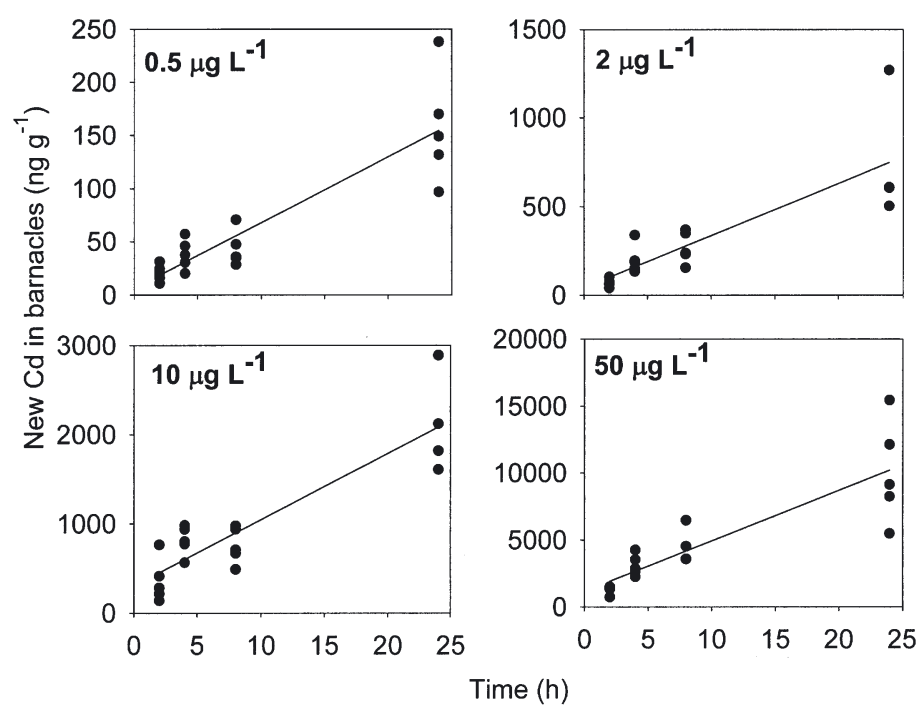

Fig. 2. Balanus amphitrite. Uptake of labelled Cd by barnacles from Tsing Yi exposed at 4 different concentrations of $\mathrm{Cd}$ in a mixture of trace metals (see 'Materials and methods') appropriate intercept (adsorbed metal concentration) from each accumulated concentration before dividing by the time of exposure, thereby obtaining an estimate of the rate of uptake of labelled $\mathrm{Cd}$ or $\mathrm{Zn}$ into the body. These estimates of uptake-rate can then be plotted against exposure concentration as shown in Fig. 3 for $\mathrm{Cd}$ and $\mathrm{Zn}$ uptake in the Tsing Yi population. In every case uptake-rate showed a significant linear increase with increasing concentration. The slope of this line (now expressed as $\mu \mathrm{g} \mathrm{g}^{-1} \mathrm{~d}^{-1}$ per $\mu \mathrm{g}^{-1}$, or $\mathrm{l} \mathrm{g}^{-1} \mathrm{~d}^{-1}$ ) is the uptake-rate constant, which is a measure of the uptake of a metal by a particular population of barnacles and can be compared between the populations by ANCOVA (Table 2).

The uptake-rate constants for both $\mathrm{Cd}$ and $\mathrm{Zn}$ did show significant differences between treatment populations (Table 2). In the case of Cd, at the same salinity (33) uptake-rate constants increased across the series Tsing $\mathrm{Yi}_{\text {, }}$ Wong Shek, Aberdeen, Tai O and Kowloon City. The populations from Tai O and Wong Shek each showed significantly higher uptake of $\mathrm{Cd}$ at the lower salinity of 15 in comparison with uptake at 33. Zn uptake also showed variation between sites, but not to the same fine degree of resolution as in the case of $\mathrm{Cd}$. At a salinity of 33, uptake-rate constants increased across the sites Aberdeen, Wong Shek, Tsing Yi, Tai O and Kowloon City. Zn uptake was significantly higher at a salinity of 15 than 33 in the case of the Wong Shek population, but not in the case of Tai $O$.

A hypothesis test for Spearman's rank correlation coefficient (allowing for tied ranks) of the ranks of sites in order of increasing uptake-rate constants for Cd and $\mathrm{Zn}$ at a salinity of 33 (Table 2) showed no significant correlation ( $5 \%$ level) between the ranks ( $\mathrm{rs}=0.289$ ). Thus $\mathrm{Cd}$ and $\mathrm{Zn}$ uptake-rates are not correlated in the 5 different populations.

No data are presented for Ag uptake from solution, because exposure concentrations were not high enough, nor experimental duration long enough, to bring about significant linear absorption of Ag into the barnacle bodies, over and above that adsorbed onto the bodies.

Assimilation efficiencies. The barnacles assimilated Ag, Cd and Zn from the ingested Thalassiosira weissflogii. Radioactive counting of faecal pellets (not shown) showed that unassimilated metal passed through the gut within $24 \mathrm{~h}$. After the egestion of unassimilated metal in the faeces, the percentage of assimilated metal remained essentially constant or declined very slowly in the $48 \mathrm{~h}$ period (Fig. 4). The AE, calculated as the \% retained in the barnacles after $24 \mathrm{~h}$ of depuration, are given in Table 3 for the 6 treatment populations.

The AE shown in Table 3 were compared by ANOVA (after arcsine transformation). In the case of all populations at a salinity of 33 , there was no significant differ- 
Table 1. Balanus amphitrite. Rates of uptake of radiolabelled Cd and $\mathrm{Zn}$ at 4 exposure concentrations (A to D) by 7 treatment populations of barnacles (salinity of 33 at 5 sites, and salinities of 15 and 33 at 2 sites), as estimated from the slope of best fit linear regressions of accumulated concentration $\left(\mathrm{ng} \mathrm{g}^{-1}\right)$ against time $(\mathrm{h})$. The intercept and probability (p) of significance of each regression are also given (ns: not significant, ${ }^{*} \mathrm{p}<0.05,{ }^{* *} \mathrm{p}<0.01,{ }^{* * *} \mathrm{p}<0.001$ )

\begin{tabular}{|c|c|c|c|c|c|c|c|c|c|c|c|c|c|}
\hline \multirow[t]{2}{*}{ Site } & \multirow[t]{2}{*}{$\begin{array}{c}\text { Cd conc. } \\
\left(\mu g \mathrm{l}^{-1}\right)\end{array}$} & \multirow[t]{2}{*}{$\mathrm{N}$} & \multicolumn{2}{|c|}{$\begin{array}{c}\text { Uptake-rate } \\
\left(\text { ng g }^{-1} \mathrm{~h}^{-1}\right)\end{array}$} & \multirow[t]{2}{*}{ Intercept } & \multirow[t]{2}{*}{$\mathrm{p}$} & \multirow[t]{2}{*}{ Site } & \multirow[t]{2}{*}{$\begin{array}{c}\text { Zn conc. } \\
\left(\mu \mathrm{gl}^{-1}\right)\end{array}$} & \multirow[t]{2}{*}{$\mathrm{N}$} & \multicolumn{2}{|c|}{$\begin{array}{c}\text { Uptake-rate } \\
\left(\text { ng g }^{-1} \mathrm{~h}^{-1}\right)\end{array}$} & \multirow[t]{2}{*}{ Intercept } & \multirow[t]{2}{*}{$\mathrm{p}$} \\
\hline & & & Mean & SE & & & & & & Mean & SE & & \\
\hline \multicolumn{7}{|c|}{ Aberdeen 33} & \multicolumn{7}{|c|}{ Aberdeen 33} \\
\hline $\mathrm{A}$ & 0.5 & 14 & 5.41 & 2.61 & 18.9 & ns & $\mathrm{A}$ & 2 & 14 & 62.1 & 22.0 & 101 & * \\
\hline B & 2 & 19 & 11.1 & 3.20 & 94.9 & $* *$ & B & 5 & 19 & 57.4 & 20.1 & 484 & $*$ \\
\hline $\mathrm{C}$ & 10 & 15 & 19.3 & 28.6 & 433 & ns & $\mathrm{C}$ & 20 & 14 & 191 & 153 & 1760 & $\mathrm{~ns}$ \\
\hline $\mathrm{D}$ & 50 & 19 & 490 & 32.8 & 366 & $* * *$ & $\mathrm{D}$ & 100 & 18 & 1410 & 103 & 4070 & $* * *$ \\
\hline \multicolumn{7}{|c|}{ Kowloon City 33} & \multicolumn{7}{|c|}{ Kowloon City 33} \\
\hline A & 0.5 & 20 & 6.21 & 0.76 & 32.3 & $* * *$ & $\mathrm{~A}$ & 2 & 20 & 34.7 & 9.0 & 437 & $* *$ \\
\hline $\mathrm{B}$ & 2 & 19 & 23.0 & 2.07 & 101 & $* * *$ & $\mathrm{~B}$ & 5 & 20 & 100 & 23.0 & 919 & $* * *$ \\
\hline $\mathrm{C}$ & 10 & 20 & 109 & 21.6 & 500 & $* * *$ & $\mathrm{C}$ & 20 & 20 & 454 & 93.8 & 2740 & $* * *$ \\
\hline $\mathrm{D}$ & 50 & 18 & 1140 & 205 & 322 & $* * *$ & $\mathrm{D}$ & 100 & 17 & 2420 & 337 & 12200 & $* * *$ \\
\hline \multicolumn{7}{|c|}{ Tsing Yi 33} & \multicolumn{7}{|c|}{ Tsing Yi 33} \\
\hline A & 0.5 & 20 & 6.18 & 0.73 & 6.06 & $* * *$ & A & 2 & 19 & 47.2 & 6.5 & 145 & $* * *$ \\
\hline $\mathrm{B}$ & 2 & 19 & 29.4 & 4.54 & 41.5 & $* * *$ & $\mathrm{~B}$ & 5 & 19 & 150 & 19.7 & 288 & $* * *$ \\
\hline $\mathrm{C}$ & 10 & 19 & 74.2 & 9.17 & 305 & $* * *$ & $\mathrm{C}$ & 20 & 18 & 362 & 48.1 & 553 & $* * *$ \\
\hline $\mathrm{D}$ & 50 & 19 & 377 & 52.6 & 1160 & $* * *$ & $\mathrm{D}$ & 100 & 18 & 2210 & 142 & 953 & $* * *$ \\
\hline \multicolumn{7}{|c|}{ Tai O 15} & \multicolumn{7}{|c|}{ Tai O 15} \\
\hline $\mathrm{A}$ & 0.5 & 18 & 11.9 & 1.03 & 30.8 & $* * *$ & A & 2 & 18 & 70.1 & 7.8 & 348 & $* * *$ \\
\hline B & 2 & 20 & 49.4 & 5.37 & 125 & $* * *$ & $\mathrm{~B}$ & 5 & 20 & 204 & 21.6 & 586 & $* * *$ \\
\hline $\mathrm{C}$ & 10 & 18 & 153 & 26.7 & 666 & $* * *$ & $\mathrm{C}$ & 20 & 18 & 723 & 147 & 751 & $* * *$ \\
\hline $\mathrm{D}$ & 50 & 16 & 313 & 103 & 526 & $* *$ & $\mathrm{D}$ & 100 & 17 & 1270 & 346 & 13300 & $* * *$ \\
\hline \multicolumn{7}{|c|}{ Tai O 33} & \multicolumn{7}{|c|}{ Tai O 33} \\
\hline A & 0.5 & 16 & 7.77 & 1.63 & -0.52 & $* *$ & A & 2 & 16 & 39.4 & 10.1 & 285 & $* *$ \\
\hline $\mathrm{B}$ & 2 & 19 & 23.4 & 3.42 & 32.7 & $* * *$ & $\mathrm{~B}$ & 5 & 18 & 73.7 & 20.3 & 638 & $* *$ \\
\hline $\mathrm{C}$ & 10 & 16 & 41.7 & 11.7 & 367 & $* *$ & $\mathrm{C}$ & 20 & 18 & 173 & 58.8 & 2440 & $* *$ \\
\hline $\mathrm{D}$ & 50 & 18 & 650 & 76.8 & -421 & $* * *$ & $\mathrm{D}$ & 100 & 18 & 1800 & 220 & 3190 & $* * *$ \\
\hline \multicolumn{7}{|c|}{ Wong Shek 33} & \multicolumn{7}{|c|}{ Wong Shek 33} \\
\hline A & 0.5 & 12 & 3.89 & 0.53 & 12.0 & $* * *$ & A & 2 & 12 & 26.3 & 8.1 & 300 & ${ }^{* *}$ \\
\hline B & 2 & 16 & 17.0 & 2.68 & 72.9 & $* * *$ & B & 5 & 16 & 79.8 & 12.0 & 421 & ${ }^{* * *}$ \\
\hline $\mathrm{C}$ & 10 & 15 & 62.6 & 14.0 & 366 & $* * *$ & $\mathrm{C}$ & 20 & 15 & 215 & 53.8 & 1370 & $* *$ \\
\hline $\mathrm{D}$ & 50 & 16 & 348 & 67.4 & 1390 & $* * *$ & $\mathrm{D}$ & 100 & 16 & 1050 & 330 & 9220 & ${ }^{* *}$ \\
\hline Won & Shek 15 & & & & & & Won & Shek 15 & & & & & \\
\hline A & 0.5 & 16 & 20.3 & 3.80 & -5.35 & $* * *$ & A & 2 & 16 & 93.9 & 13.3 & 15.2 & $* * *$ \\
\hline B & 2 & 15 & 62.6 & 5.01 & 66.3 & $* * *$ & B & 5 & 15 & 141 & 29.8 & 649 & $* * *$ \\
\hline $\mathrm{C}$ & 10 & 13 & 508 & 50.5 & -907 & $* * *$ & $\mathrm{C}$ & 20 & 13 & 1740 & 335 & -2800 & $* * *$ \\
\hline $\mathrm{D}$ & 50 & 16 & 587 & 194 & 6510 & $* *$ & $\mathrm{D}$ & 100 & 16 & 1780 & 478 & 23000 & ${ }^{* *}$ \\
\hline
\end{tabular}

ence between populations of the AE of any of the 3 metals $(p>0.05)$. In a comparison of assimilation efficiencies of the Tai O population at salinities of 15 and 33 , there was no significant difference between $\mathrm{AE}$ for any of the 3 trace metals.

Efflux-rates. The efflux of accumulated $\mathrm{Ag}, \mathrm{Cd}$ and Zn from barnacles fed daily pulses of radiolabelled Thalassiosira weissflogii for $6 \mathrm{~d}$, followed by $30 \mathrm{~d}$ feeding on non-labelled diatoms, are shown in Fig. 5 and Table 4. Depuration of assimilated metals was 2- compartmental, and each compartment can be modelled using exponential loss. There was significant variation of the \% of $\mathrm{Ag}$ retained in the barnacles over the $30 \mathrm{~d}$ depuration period. The efflux-rate constant was calculated from the slope of the linear regression between the $\ln \%$ retained in barnacles against the time of depuration in the slower exchangeable compartment (6 to $30 \mathrm{~d}$ of depuration). The biological retention half-life was calculated as 0.693 divided by the efflux-rate constant. 

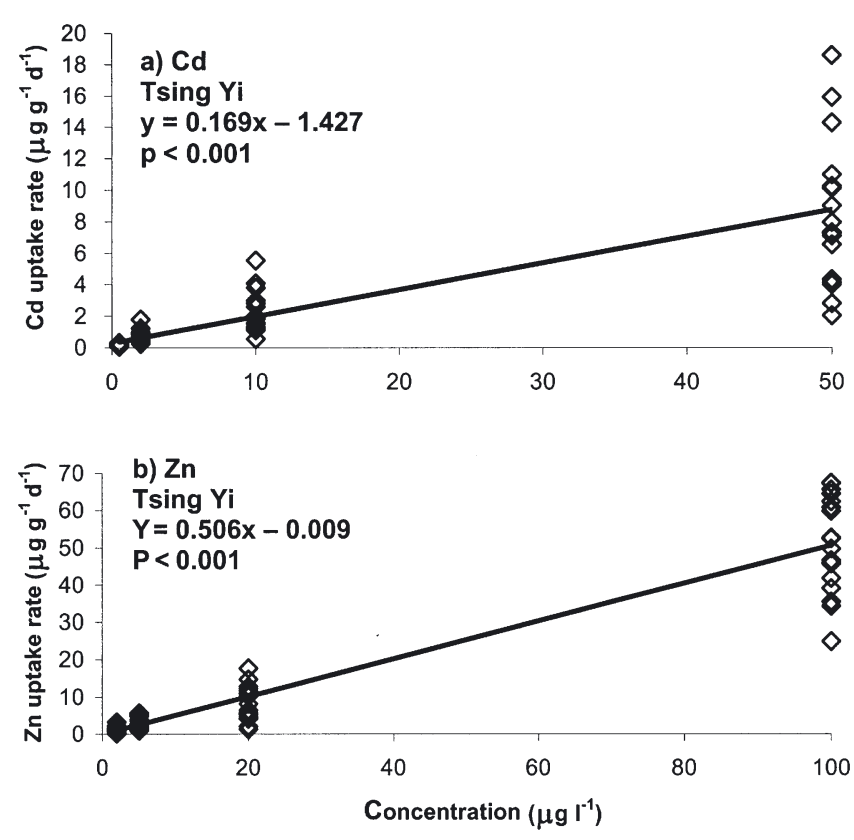

Fig. 3. Balanus amphitrite. uptake-rates of (a) labelled Cd and (b) labelled Zn by barnacles from Tsing Yi plotted against dissolved exposure concentrations in order to estimate uptakerate constants for $\mathrm{Cd}$ and $\mathrm{Zn}$

Efflux-rates of the 3 assimilated metals were very low, and biological half-lives varied from 98 to $396 \mathrm{~d}$ for $\mathrm{Ag}$, 92 to $163 \mathrm{~d}$ for $\mathrm{Cd}$ and 165 to $560 \mathrm{~d}$ for $\mathrm{Zn}$. There was no

Table 2. Balanus amphitrite. Uptake-rate constant $\left(k_{\mathrm{u}}, \mathrm{l} \mathrm{g}^{-1} \mathrm{~d}^{-1} \pm \mathrm{SE}\right.$ and $95 \%$ confidence limits; CL) of radiolabelled $\mathrm{Cd}$ and $\mathrm{Zn}$ of 7 treatment populations of barnacles, as estimated from the slope of best-fit linear regressions of uptakerate $\left(\mu \mathrm{g} \mathrm{g}^{-1} \mathrm{~d}^{-1}\right)$ against exposure concentration $\left(\mu \mathrm{g}^{-1}\right)$. Uptake-rate constants sharing a letter under each metal do not differ significantly $(p>0.05)$

\begin{tabular}{|lccccccc|}
\hline & $k_{\mathrm{u}}$ & SE & $\begin{array}{c}95 \% \\
\mathrm{CL}\end{array}$ & \multicolumn{2}{c|}{$\begin{array}{c}\text { ANCOVA } \\
\text { Comparison of slopes }\end{array}$} \\
\hline Cd & & & & & & & \\
Tsing Yi 33 & 0.169 & 0.014 & 0.060 & $\mathrm{~A}$ & & & \\
Wong Shek 33 & 0.192 & 0.019 & 0.080 & $\mathrm{~A}$ & $\mathrm{~B}$ & & \\
Aberdeen 33 & 0.237 & 0.014 & 0.059 & & $\mathrm{~B}$ & & \\
Tai O 33 & 0.302 & 0.021 & 0.092 & & & $\mathrm{C}$ & \\
Tai O 15 & 0.486 & 0.032 & 0.136 & & & D & \\
Wong Shek 15 & 0.581 & 0.067 & 0.287 & & & D & E \\
Kowloon City 33 & 0.656 & 0.057 & 0.244 & & & & E \\
& & & & & & & \\
Zn & & & & & & & \\
Aberdeen 33 & 0.339 & 0.029 & 0.124 & A & & & \\
Wong Shek 33 & 0.363 & 0.058 & 0.250 & A & & & \\
Tai O 15 & 0.472 & 0.047 & 0.203 & A & B & & \\
Tsing Yi 33 & 0.506 & 0.020 & 0.086 & & B & & \\
Tai O 33 & 0.521 & 0.047 & 0.202 & & B & & \\
Wong Shek 15 & 0.587 & 0.082 & 0.352 & & B & & \\
Kowloon City 33 & 0.616 & 0.049 & 0.213 & & B & & \\
\hline
\end{tabular}

significant difference by ANOVA between the effluxrates of different population treatments for any metal (Table 4).

Fractionation and metal concentrations in barnacles. Fig. 6 shows the distribution of newly accumulated (i.e. radiolabelled) metals in barnacles from each population treatment after $6 \mathrm{~d}$ feeding on radiolabelled diatoms and also after a further $30 \mathrm{~d}$ feeding on non-labelled diatoms. The distributions are very similar in the 2 categories of barnacles. Most of the newly accumulated metal is in an insoluble form with $10 \%$ or less bound to MTLP.

The weight-adjusted mean accumulated metal concentrations in the bodies of the barnacles collected from the 5 sites are shown in Table 5 . Figs. $7 \& 8$ show these accumulated metal concentrations plotted against the dissolved uptake-rate constants (at a salinity of 33) for $\mathrm{Cd}$ and $\mathrm{Zn}$, and against the $\mathrm{AE}$ for $\mathrm{Ag}, \mathrm{Cd}$ and $\mathrm{Zn}$. Both figures indicate no relationship between accumulated metal concentrations and either uptake from solution or assimilation efficiency from food. Spearman's rank correlations (allowing for tied ranks) were therefore calculated to test statistically for any significant correlations between the accumulated concentrations of $\mathrm{Cd}$ and $\mathrm{Zn}$ and their dissolved uptake-rate constants; this was not effected for the assimilation efficiency data, given the lack of significant differences between AE of barnacles from the different populations (see above). For both $\mathrm{Cd}$ and $\mathrm{Zn}$, there was no significant correlation between the ranks of sites in order of accumulated concentration and that of uptake-rate constant $\left(r_{\mathrm{S}}=0.667\right.$ for $\mathrm{Cd}, r_{\mathrm{S}}=$ -0.148 for $\mathrm{Zn})$. As a further test, the individual AE summarised in Fig. 8 were regressed against weight-adjusted mean metal concentrations across the 5 treatment populations at a salinity of 33. In no case was the regression significant $(p>0.05)$.

\section{DISCUSSION}

The hypothesis under test was that differential metal pre-exposure in the field affects the AE of that metal and its rate of uptake from solution. Since there were no significant differences between the AE of all 3 metals in the different populations under the same experimental conditions, it is clear that previous field-contamination history had no effect on assimilation. On the other hand, dissolved $\mathrm{Cd}$ and $\mathrm{Zn}$ uptake-rate constants did vary significantly between populations under the same experimental conditions, and the question 

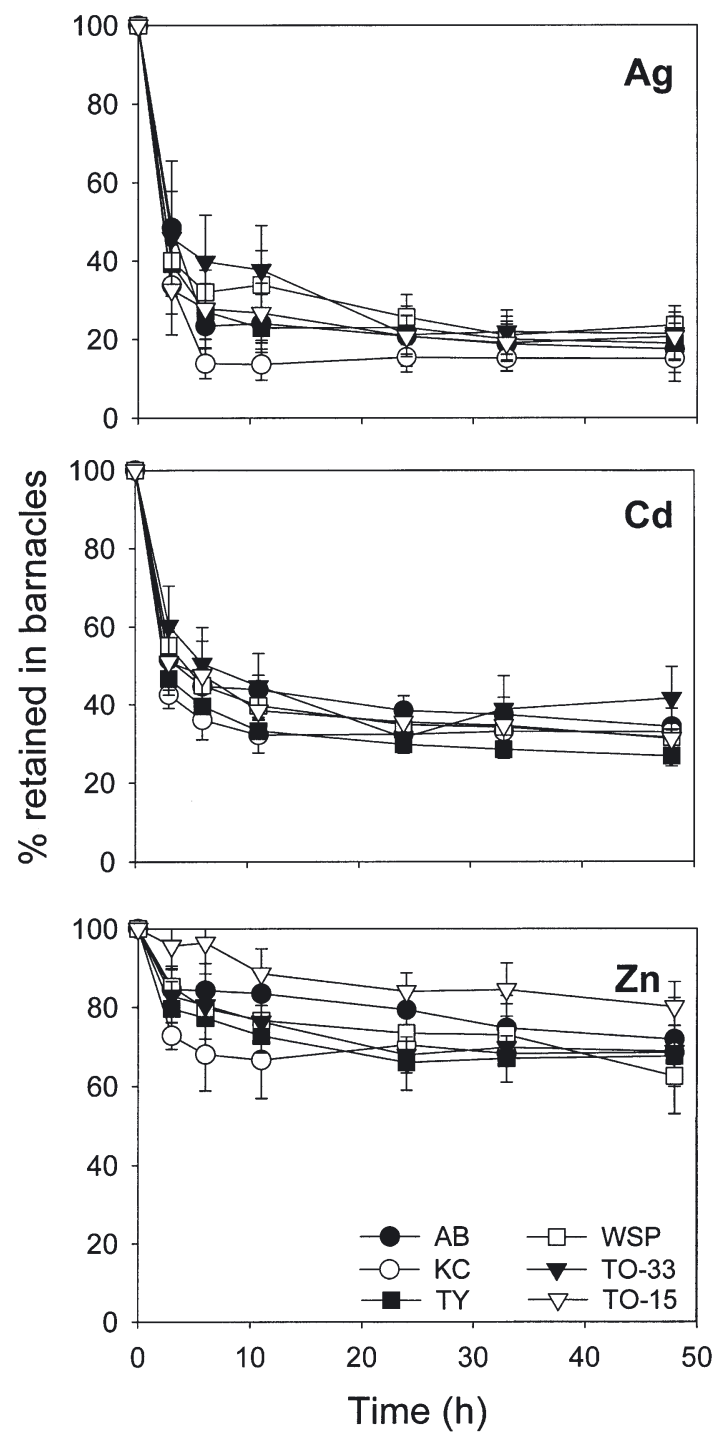

Fig. 4. Balanus amphitrite. Retention of $\mathrm{Ag}, \mathrm{Cd}$ and $\mathrm{Zn}$ (mean $\pm \mathrm{SD}, \mathrm{n}=5$ ) by 6 different treatment populations of barnacles following pulse-feeding on radiolabelled diatoms Thalassiosira weissflogii. AB: Aberdeen; KC: Kowloon City; TY: Tsing Yi; WSP: Wong Shek; TO-33: Tai O, 33 salinity; TO-15: Tai O, 15 salinity

remained whether these differences are related to previous contaminant exposure history. Body accumulated metal concentrations are integrated measures of the previous exposure of the barnacle to that metal (Phillips \& Rainbow 1994, Wang \& Rainbow 2000, Rainbow \& Blackmore 2001), and are therefore excellent surrogate measures of previous contaminant history. For neither Zn nor Cd, however, was there a significant correlation between accumulated metal concentration and metal uptake-rate from solution. Thus, previous field-exposure history had no significant effect on subsequent uptake of $\mathrm{Zn}$ or Cd from solution.
In a recent laboratory study on the green mussel Perna viridis (Blackmore \& Wang 2002), pre-exposure to the respective metal in the laboratory did increase Cd but not Zn AE from the diatom food Thalassiosira pseudonana, and $\mathrm{Cd}$ assimilation inconsistently increased after $\mathrm{Zn}$ pre-exposure. Similarly, laboratory pre-exposure to Ag increased Ag assimilation in the same mussel (Shi et al. 2003). Given the nature of laboratory experiments, such pre-exposure to a dissolved metal will inevitably involve higher dissolved concentrations and shorter time periods than chronic pre-exposure in the field, and it remains likely that metal detoxification systems (e.g. turnover of MT) are active to a greater extent after laboratory pre-
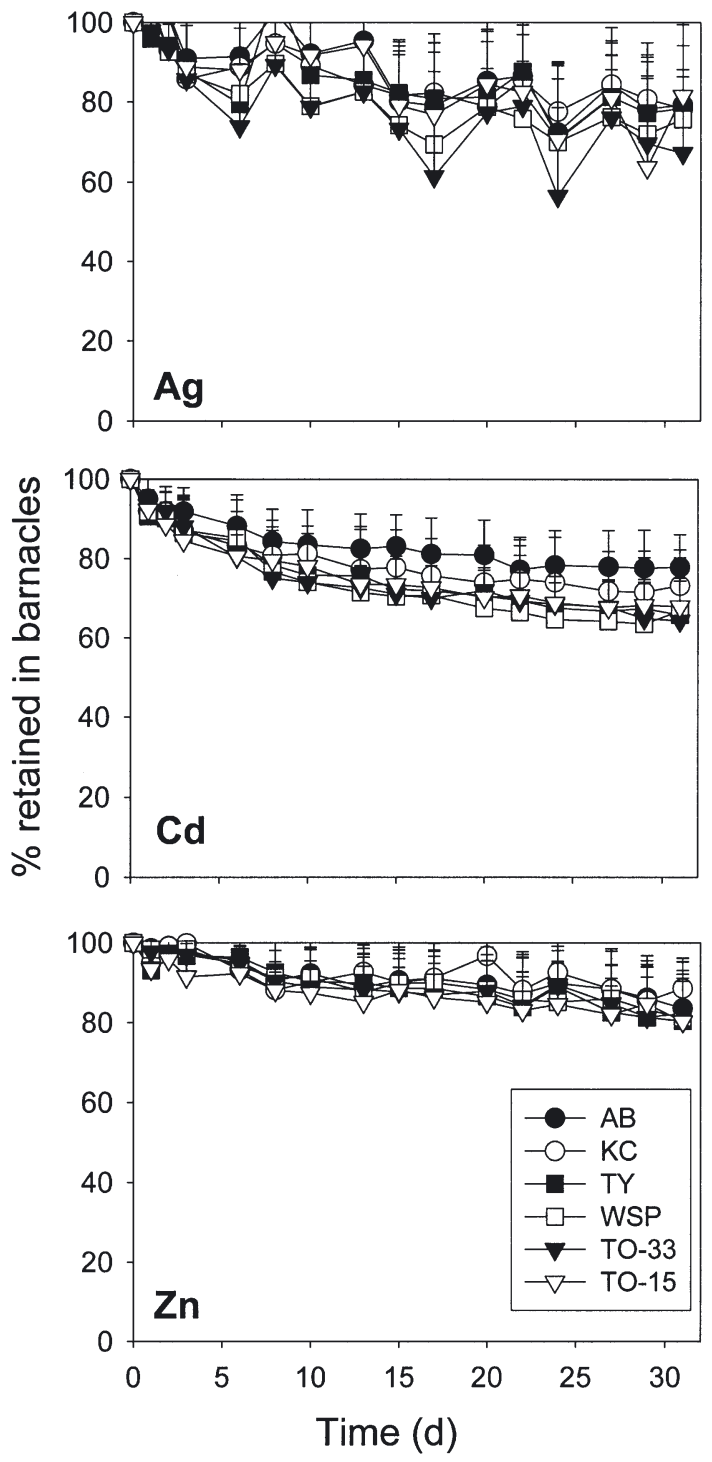

Fig. 5. Balanus amphitrite. Efflux of accumulated radiolabelled $\mathrm{Ag}, \mathrm{Cd}$ and $\mathrm{Zn}$ from barnacles fed for $6 \mathrm{~d}$ with radiolabelled diatoms Thalassiosira weissflogii (mean $+\mathrm{SD}, \mathrm{n}=10$ ). Same site abbreviations as Fig. 4 
Table 3. Balanus amphitrite. Assimilation efficiencies (AE) $(\%$; mean $\pm \mathrm{SD}, \mathrm{n}=5)$ of $\mathrm{Ag}, \mathrm{Cd}$ and $\mathrm{Zn}$ in barnacles of 6 treatment populations feeding on Thalassiosira weissflogii after $24 \mathrm{~h}$ of depuration. $\mathrm{p}$ is the probability that there is no difference between the AE compared (ANOVA on arcsine transformed data)

\begin{tabular}{|lccc|}
\hline Site salinity & $\mathrm{Ag}$ & $\mathrm{Cd}$ & $\mathrm{Zn}$ \\
\hline Tai O 33 & $35.6 \pm 28.2$ & $41.5 \pm 20.0$ & $68.9 \pm 6.6$ \\
Tsing Yi 33 & $18.9 \pm 10.1$ & $26.8 \pm 6.5$ & $67.7 \pm 18.9$ \\
Aberdeen 33 & $17.5 \pm 20.3$ & $34.3 \pm 11.5$ & $71.9 \pm 25.8$ \\
Kowloon City 33 & $15.0 \pm 8.9$ & $32.9 \pm 5.7$ & $68.6 \pm 5.4$ \\
Wong Shek 33 & $23.6 \pm 11.9$ & $31.5 \pm 8.7$ & $62.6 \pm 23.3$ \\
p & 0.459 & 0.338 & 0.865 \\
Tai O 15 & $20.6 \pm 15.2$ & $31.2 \pm 9.4$ & $80.1 \pm 15.6$ \\
Tai O 33 & $35.6 \pm 28.2$ & $41.5 \pm 20.0$ & $68.9 \pm 6.6$ \\
p & 0.327 & 0.330 & 0.163 \\
\hline
\end{tabular}

trace metal bioavailabilities vary over a wide gradient in Hong Kong coastal waters, they would not approach those expected to select for metal tolerance in the barnacle populations even at the high end of the local environmental gradient. It might also be relevant that the majority of each accumulated metal was associated with the insoluble fraction in the barnacle body. Such insoluble metal stores are considered physiologically 'inert' (Rainbow 2002), so any influences of metal pre-exposure on metal bioavailability in barnacles may be less significant than in bivalves, in which metals may be bound to more physioexposure (with more likely consequences for uptakerates) than in a field situation of increased availability. The lack of an observed increase in AE in the fieldcollected barnacles exposed to higher availabilities may therefore be reconcilable with the laboratory-based observations of Blackmore \& Wang (2002) and Shi et al. (2003) on mussels. It must be remembered that, although

logically active sites (e.g. MT) (Langston et al. 1998).

Nevertheless, the assimilation of $\mathrm{Cd}$ and $\mathrm{Hg}$ (but not Zn) was significantly increased in dogwhelks Thais clavigera with high MT concentrations after pre-exposure in the field as well as in the laboratory (G. Blackmore \& W.$\mathrm{X}$. Wang unpubl.). This interspecific variation in sensitivity to respond to different degrees of metal pre-exposure may well be related to the great intertaxon differences in induction, concentrations and turnover of MT in different invertebrates (see Langston et al. 1998).

Dissolved uptake was not increased in Balanus amphitrite by increased preexposure to metal in the field. This result is consistent with the little information available in the literature. Rainbow et al. (1999) found no consistent pattern in the rates of uptake of $\mathrm{Ag}, \mathrm{Cd}$ and $\mathrm{Zn}$ from solution in the amphipod crustacean Orchestia gammarellus or the crabs Carcinus maenas and Pachygrapsus marmoratus from coastal sites in France and Britain differentially enriched with trace metals. Similarly, neither Cd or Zn uptake from solution was enhanced by laboratory pre-exposure to that metal in Perna viridis (Blackmore \& Wang 2002), nor were uptake-rates of $\mathrm{Cd}, \mathrm{Hg}$ or $\mathrm{Zn}$ from solution after either laboratory or field pre-exposure in Thais clavigera (G. Blackmore \& W.-X. Wang unpubl.). On the other hand, when field exposure of the polychaete Nereis diversicolor to $\mathrm{Cu}$ in the field (in this case $\mathrm{Re}$ stronguet Creek, England) is high enough to select for a Cu-tolerant population, the $\mathrm{Cu}$ uptake-rate from solu- 

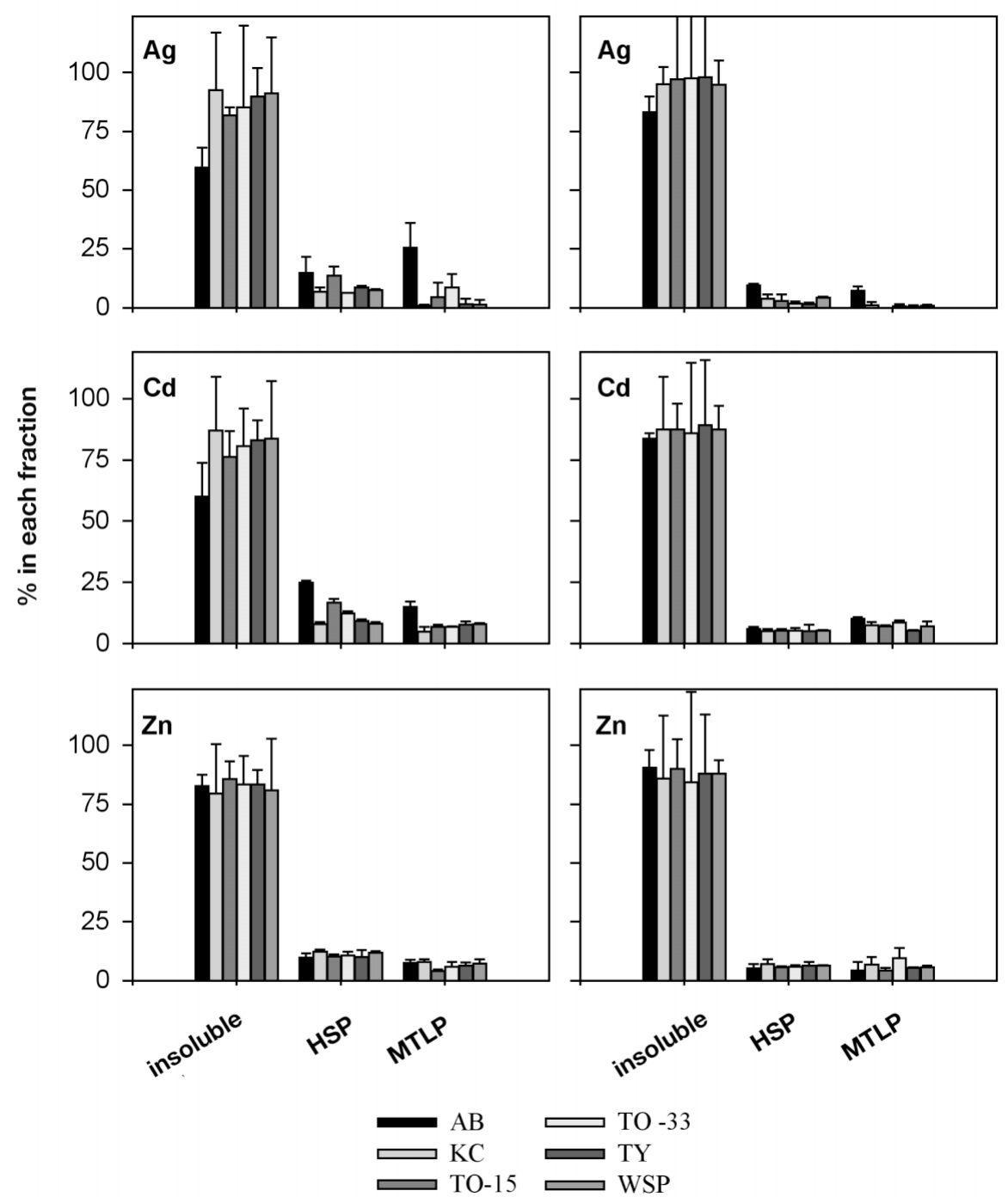

Fig. 6. Balanus amphitrite. Fractionation of accumulated radiolabelled Ag, Cd and $\mathrm{Zn}$ into soluble (metallothionein-like proteins; MTLP) and other (heat-sensitive) proteins (HSP) and insoluble components (\%; mean + SD) in barnacles fed for $6 \mathrm{~d}$ on radiolabelled diatoms Thalassiosira weissflogii (left panel) and in barnacles following $30 \mathrm{~d}$ depuration feeding on non-labelled diatoms (right panel). Same site abbreviations as Fig. 4

tion is significantly raised in comparison to other field populations (Bryan \& Hummerstone 1971, Bryan 1974, 1976).

Thus there will be occasions when even field availabilities will be so high that the interaction with the metal detoxification system, developed in a particular invertebrate taxon, will promote a change in the rate of uptake of that metal from solution. This does not, however, seem to be a widespread phenomenon, although it is worthy of further research.

As reviewed by Rainbow (1998), trace-metal uptakerates in barnacles are amongst the highest for crustaceans. The uptake-rate constants $\left(k_{\mathrm{u}}\right)$ measured in this study for Balanus amphitrite are in good correspondence with those in the literature. At $23^{\circ} \mathrm{C}$ and a salinity of 33, uptake-rate constants for $B$. amphitrite varied from 0.169 to $0.656 \mathrm{l} \mathrm{g}^{-1} \mathrm{~d}^{-1}$ for $\mathrm{Cd}$, and 0.339 to $0.616 \mathrm{l} \mathrm{g}^{-1} \mathrm{~d}^{-1}$ for $\mathrm{Zn}$ (Table 2). Uptake-rate constants for the temperate barnacle Elminius modestus at $10^{\circ} \mathrm{C}$ and a salinity of 33 (in a reproducible artificial seawater [TMN] medium) are 0.087 to $0.125 \mathrm{l} \mathrm{g}^{-1} \mathrm{~d}^{-1}$ for $\mathrm{Cd}$ and 0.270 to 0.370 for $\mathrm{Zn}$ (from Rainbow \& White 1989, 1990, Rainbow 1998). Cd uptake-rate constants for other crustaceans in the same artificial seawater medium at $10^{\circ} \mathrm{C}$ and a salinity of 33 are lower, being 0.017 to 0.023 for the amphipod Echinogammarus pirloti, and 0.0023 for the caridean decapod Palaemon elegans (Rainbow \& White 1989, 1990). Zn uptake-rate constants under these same conditions are also lower than in barnacles: 0.026, 0.014 and $0.013 \mathrm{l} \mathrm{g}^{-1} \mathrm{~d}^{-1}$ for the amphipods Echinogammarus pirloti, Orchestia gammarellus and $O$. mediterranea, 0.015 to 0.020 and 0.047 $1 \mathrm{~g}^{-1} \mathrm{~d}^{-1}$ for the caridean decapods Palaemon elegans and Pandalus montagui, and ca. 0.004 for the crab Carcinus maenas (from Rainbow \& White 1989, 1990, Rainbow 1998). Bivalve uptake-rate constants for $\mathrm{Cd}$ and $\mathrm{Zn}$ (Wang 2001) are more like those of barnacles, with which they share the characteristic of moving high volumes of water across large permeable surface areas (Rainbow 1998). Thus, uptake-rate constants $\left(\mathrm{l} \mathrm{g}^{-1} \mathrm{~d}^{-1}\right)$ for Perna viridis, Septifer virgatus and Ruditapes philippinarum are 0.182, 0.180 and $0.054 \mathrm{l} \mathrm{g}^{-1} \mathrm{~d}^{-1}$ respectively for $\mathrm{Cd}$, and $0.483,0.350$ and $0.191 \mathrm{lg}^{-1} \mathrm{~d}^{-1}$ respectively for $\mathrm{Zn}$ (Wang 2001).

AE measured in this study for Balanus amphitrite at a salinity of 33 varied from 15.0 to $35.6 \%$ for $\mathrm{Ag}, 26.8$ to $41.5 \%$ for Cd and 62.6 to $71.9 \%$ for Zn (Table 3). Comparative AE data for $\mathrm{Cd}$ and $\mathrm{Zn}$ for barnacles at comparable temperatures have been listed by Rainbow \& Wang (2001); Ag assimilation efficiencies for barnacles have not been measured before. Cd AE for Elminius modestus, Balanus trigonus and B. amphitrite feeding on diatoms varied from 25.5 to $86.2 \%$, encompassing the range measured in this study; equivalent $\mathrm{Zn}$ AE ranged from 76.1 to $92.2 \%$; above the values measured here. AE 
Table 5. Balanus amphitrite. Accumulated field concentrations of $\mathrm{Ag}, \mathrm{Cd}, \mathrm{Zn}, \mathrm{Cu}$ and $\mathrm{Cr}$ in barnacles collected at 5 sites expressed as the weight adjusted mean $\left(\mu \mathrm{g} \mathrm{g}^{-1}\right)$. Concentrations of populations sharing a letter under ANCOVA for one metal do not differ significantly $(p>0.05)$ for that metal

\begin{tabular}{|c|c|c|}
\hline Site & $\begin{array}{c}\text { Weight adjusted } \\
\text { mean } \pm \mathrm{SE}\end{array}$ & Post hoc \\
\hline \multicolumn{3}{|l|}{ Ag } \\
\hline Kowloon City & $6.24 \pm 0.52$ & $\mathrm{~A}$ \\
\hline Tsing Yi & $5.46 \pm 0.43$ & $\mathrm{~A}$ \\
\hline Aberdeen & $2.75 \pm 0.33$ & B \\
\hline Wong Shek & $1.17 \pm 0.13$ & $\mathrm{C}$ \\
\hline Tai O & $0.85 \pm 0.07$ & $\mathrm{D}$ \\
\hline \multicolumn{3}{|l|}{ Cd } \\
\hline Tai O & $6.41 \pm 0.51$ & $\mathrm{~A}$ \\
\hline Aberdeen & $2.84 \pm 0.32$ & $\mathrm{~B}$ \\
\hline Kowloon City & $2.22 \pm 0.17$ & $\mathrm{~B}, \mathrm{C}$ \\
\hline Tsing Yi & $2.01 \pm 0.15$ & $\mathrm{C}$ \\
\hline Wong Shek & $1.87 \pm 0.19$ & $\mathrm{C}$ \\
\hline \multicolumn{3}{|l|}{ Zn } \\
\hline Aberdeen & $9410 \pm 883$ & $\mathrm{~A}$ \\
\hline Kowloon City & $6540 \pm 422$ & B \\
\hline Tsing Yi & $3440 \pm 211$ & $\mathrm{C}$ \\
\hline Wong Shek & $2340 \pm 202$ & $\mathrm{D}$ \\
\hline Tai O & $1970 \pm 132$ & $\mathrm{D}$ \\
\hline \multicolumn{3}{|l|}{$\mathrm{Cu}$} \\
\hline Aberdeen & $1130 \pm 129$ & $\mathrm{~A}$ \\
\hline Kowloon City & $405 \pm 31.5$ & B \\
\hline Tsing Yi & $354 \pm 26.2$ & B \\
\hline Wong Shek & $135 \pm 14.1$ & $\mathrm{C}$ \\
\hline Tai O & $107 \pm 8.62$ & $\mathrm{C}$ \\
\hline \multicolumn{3}{|l|}{$\mathrm{Cr}$} \\
\hline Aberdeen & $5.69 \pm 0.89$ & $\mathrm{~A}$ \\
\hline Tai O & $2.48 \pm 0.27$ & B \\
\hline Kowloon City & $2.20 \pm 0.24$ & B \\
\hline Tsing Yi & $2.19 \pm 0.22$ & B \\
\hline Wong Shek & $1.34 \pm 0.19$ & $\mathrm{C}$ \\
\hline
\end{tabular}

depend on gut passage times (and therefore food quantities and ingestion rates) and on food type (Wang \& Fisher 1999b, Xu \& Wang 2001, Wang 2002), and any intraspecific differences in AE between studies may be explained by such factors. To generalise across marine invertebrates, the assimilation efficiencies of barnacles are relatively typical in the case of $\mathrm{Cd}$, but high for $\mathrm{Zn}$ (Rainbow \& Wang 2000, Blackmore \& Wang 2002, Wang 2002).

Efflux-rate constants $\left(k_{\mathrm{e}}\right)$ for accumulated trace metals in barnacles are very low relative to those of many invertebrates, matched only by gastropod molluscs (Rainbow \& Wang 2001, Wang 2002). This general conclusion is corroborated by the results obtained here for Balanus amphitrite. Efflux-rate constants for $\mathrm{Cd}$ in B. amphitrite ranged from 0.0047 to $0.0095 \mathrm{~d}^{-1}$, even lower than in Elminius modestus (0.0181 d ${ }^{-1}$; Rainbow \& Wang 2001).
The $\mathrm{k}_{\mathrm{e}}\left(0.0022 \mathrm{~d}^{-1}\right)$ for $\mathrm{Zn}$ in E. modestus (Rainbow \& Wang 2001) is within the range $\left(0.0015\right.$ to $\left.0.0058 \mathrm{~d}^{-1}\right)$ measured here for $B$. amphitrite. Efflux-rate constants for Ag in barnacles are presented here for the first time, and the range ( 0.0053 to $\left.0.0104 \mathrm{~d}^{-1}\right)$ is similar to that for $\mathrm{Cd}$. Thus, accumulated trace metals have long half-lives in $B$. amphitrite, consistent with the observation here that most newly accumulated $\mathrm{Ag}, \mathrm{Cd}$ and $\mathrm{Zn}$ is stored in insoluble form (Fig. 6). Barnacles store accumulated Zn and other trace metals in pyrophosphate granules in tissues below the midgut (Rainbow 1987, 1998, Pullen \& Rainbow 1991). These granules have no access to excretion routes from the body, and accumulate over time. Metallothioneins may play a role in the delivery of $\mathrm{Zn}$ and Cd to the pyrophosphate granules (Rainbow 1998), and the small proportions of newly accumulated metal found bound to MTLP in this study may reflect this transitory role. $\mathrm{Cu}$ accumulated in excessive amounts by barnacles, on the other hand, is found not in the pyrophosphate granules but in sulphur-rich deposits (Walker 1977), which may be lysosomal residual bodies resulting from the autolysis of Cu-rich MT (Rainbow 1998). Some $\mathrm{Cd}$ may be in either insoluble form. The stored form of Ag is not known, with sulphide a further candidate, as observed in bivalves (Berthet et al. 1992).

Thus, barnacles have high uptake-rates of trace metals from solution, high $\mathrm{AE}$ and low efflux-rates of trace metals. These features make them ideal candidates as biomonitors of trace metal availabilities in coastal waters.
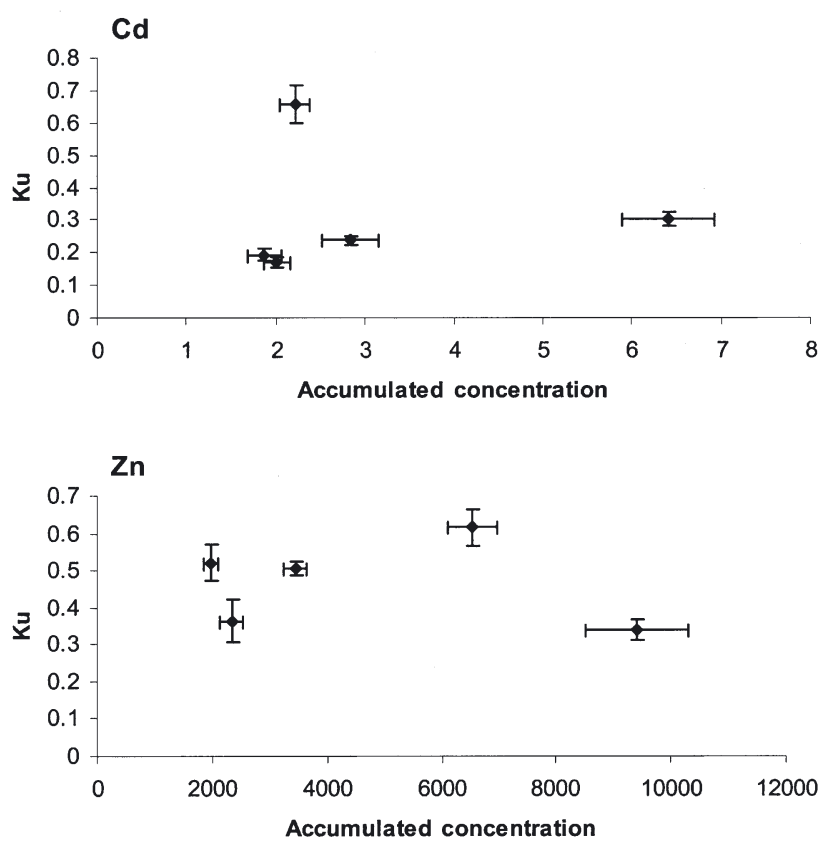

Fig. 7. Balanus amphitrite. Accumulated trace-metal concentrations (weight-adjusted means, $\mu \mathrm{g} \mathrm{g}^{-1}, \pm \mathrm{SE}$ ) in barnacles from 5 sites (from field data) against $\mathrm{Cd}$ and $\mathrm{Zn}$ uptake-rate constants $\left(\mathrm{l} \mathrm{g}^{-1} \mathrm{~d}^{-1}, \pm \mathrm{SE}\right)$ measured in the laboratory 
Indeed, barnacles, including Balanus amphitrite, have been used to detect both geographical and temporal changes in such availabilities (Rainbow 1995b, Rainbow \& Blackmore 2001). Perhaps surprisingly, given their high uptake-rates from solution, barnacles appear to accumulate by far the biggest proportion of their trace metal contents from the diet as a result of their very high $\mathrm{AE}$ and ingestion rate (Wang et al. 1999b, Rainbow \& Wang 2001), reinforcing the need for the recent research interest in the diet as a source of trace metals to marine invertebrates (Wang \& Fisher 1999a,b, Wang 2002).

This study also provides data on the effects of low salinity on trace metal uptake-rates from solution, $\mathrm{AE}$ and efflux-rates. In the case of dissolved uptake, a decrease of salinity from 33 to 15 reduces the chloride complexation of both $\mathrm{Cd}$ and $\mathrm{Zn}$ in solution, thereby promoting increased uptake, as predicted by the increased availability of the free metal ion (Rainbow 1995a, 1997, Rainbow \& Black 2002). The Wong Shek population of barnacles, collected from a full salinity 33 medium, did indeed show a significantly increased uptake of both $\mathrm{Cd}$ and $\mathrm{Zn}$ at a
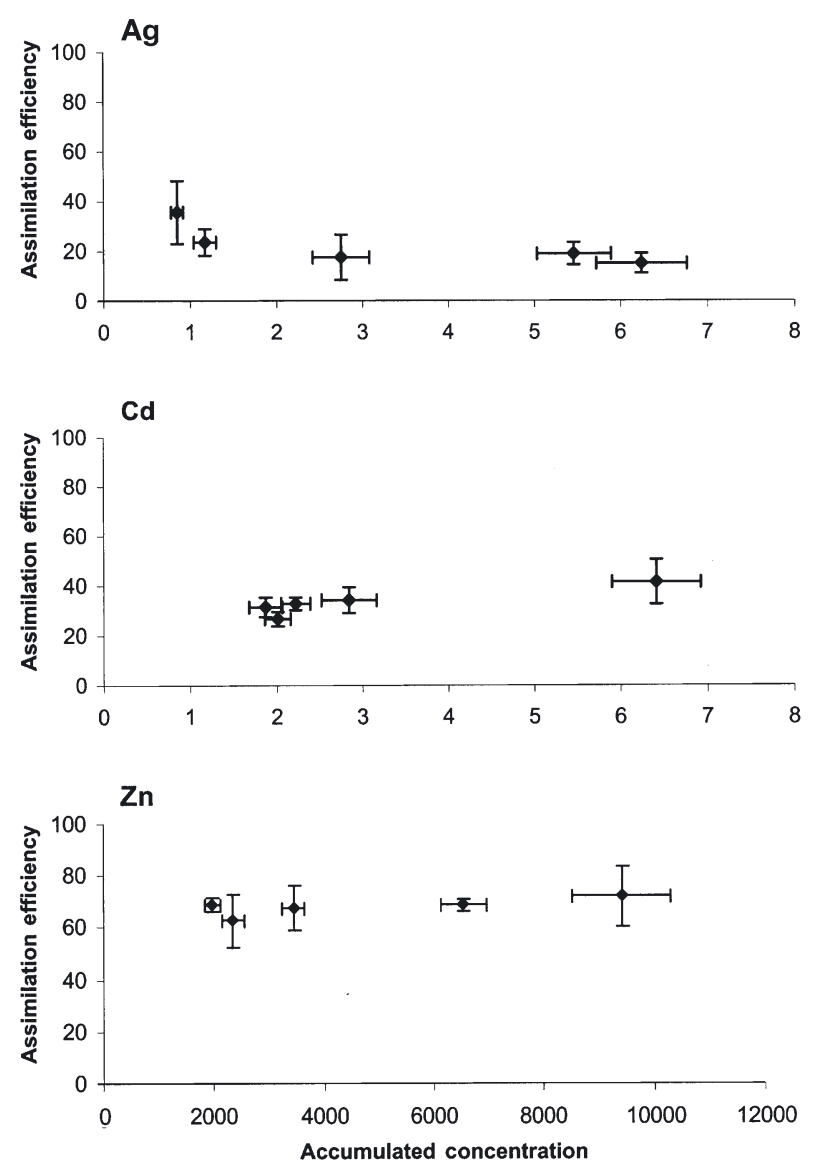

Fig. 8. Balanus amphitrite. Accumulated trace-metal concentrations (weight-adjusted means, $\mu \mathrm{g} \mathrm{g}^{-1} \pm \mathrm{SE}$ ) in barnacles from 5 sites (from field data) against $\mathrm{Ag}, \mathrm{Cd}$ and $\mathrm{Zn}$ assimilation efficiencies (mean $\% \pm \mathrm{SE}$ ) measured in the laboratory salinity of 15, compared to 33 (Table 2 ). The Tai O population experiences low salinities, in the range 6 to 20 , during the summer, and full strength seawater in the winter. The Tai O barnacles might therefore be expected to show some physiological acclimation to low salinity, which might include changes to apparent water permeability (Rainbow 1997, Rainbow \& Black 2002). These barnacles did show a significantly increased uptake-rate of Cd at the lower salinity, but not of Zn (Table 2). The physicochemical release of the free metal ion from chloride complexation with reduced salinity is more pronounced for Cd than Zn (Rainbow 1995a). It remains possible, therefore, that the Tai O population of Balanus amphitrite has made some physiological acclimation to low salinity, sufficient to offset the physicochemical changes causing increased $\mathrm{Zn}$ uptake but not the stronger physicochemical effects in the case of Cd. Rainbow \& Black (2002) discuss the presence of such physiological effects in decapod crustaceans. Furthermore, Blackmore \& Wang (2003) have demonstrated that reduced metal uptake in low versus high salinity populations in the green mussel Perna viridis was related to lower apparent water permeabilities.

The assimilation efficiencies of $\mathrm{Ag}, \mathrm{Cd}$ and $\mathrm{Zn}$ by Tai $\mathrm{O}$ barnacles did not differ at salinities of 15 and 33 (Table 3). As in the case of $\mathrm{Cd}$, chloride complexation of $\mathrm{Ag}$ in seawater (Bruland 1983) would be much reduced in lower salinities. It is likely, therefore, that physicochemical complexation effects are of minor significance in determining the availabilities of trace metals released by digestion of food in the gut. Alternatively, any physiological acclimation on the part of the Tai O barnacles to low salinity has offset any such physicochemical effects in the gut. Decreased salinity also had no significant effect of the efflux-rate constants of any of $\mathrm{Ag}, \mathrm{Cd}$ or $\mathrm{Zn}$ in Balanus amphitrite from Tai O (Table 4), as to be expected if most of the accumulated metal is bound in insoluble form without access to external epithelia.

Therefore, previous field exposure history of the barnacle Balanus amphitrite to selected trace metals has not affected the uptake-rates of the metals from solution, nor their AE. It remains to be shown whether increased exposure to raised trace metal availabilities in the laboratory will be sufficient to cause changes in uptake-rate or AE by stronger induction of detoxification systems removing newly accumulated metals from metabolic availability (Rainbow 2002). It will correspondingly be relevant to enquire whether field exposure to metal availabilities sufficiently high to cause selection of metal-tolerant strains will change metal uptake-rates. Both these lines of enquiry are now being pursued in an extension of this study.

Acknowledgements. We are grateful to Shi Dalin for his assistance in the laboratory. This study was supported by 
Competitive Earmarked Research Grants from the Hong Kong Research Grants Council (HKUST6118/01M, HKUST6097/02M) awarded to W.X.W.

\section{LITERATURE CITED}

Berthet B, Amiard JC, Amiard-Triquet C, Martoja M, Jeantet AY (1992) Bioaccumulation, toxicity and physicochemical speciation of silver in bivalve mollusks: ecotoxicological and health consequences. Sci Total Environ 125:97-122

Blackmore G, Wang WX (2002) Uptake and efflux of Cd and Zn by the green mussel Perna viridis after metal preexposure. Environ Sci Technol 36:989-995

Blackmore G, Wang WX (2003) Inter-population differences in $\mathrm{Cd}, \mathrm{Cr}, \mathrm{Se}$, and $\mathrm{Zn}$ accumulation by the green mussel Perna viridis acclimated at different salinities. Aquat Toxicol 62:205-218

Bruland KW (1983) Trace elements in seawater. In: Riley JP, Chester R (eds) Chemical oceanography, Vol. 8. Academic Press, London, p 157-220

Bryan GW (1974) Adaptation of an estuarine polychaete to sediments containing high concentrations of heavy metals. In: Vernberg FJ, Vernberg WB (eds) Pollution and physiology of marine organisms. Academic Press, New York, p 123-135

Bryan GW (1976) Some aspects of heavy metal tolerance in aquatic organisms. In: Lockwood APM (ed) Effects of pollutants on aquatic organisms. Cambridge University Press, Cambridge, p 7-34

Bryan GW, Hummerstone LG (1971) Adaptation of the polychaete Nereis diversicolor to estuarine sediments containing high concentrations of heavy metals. I. General observations and adaptation to copper. J Mar Biol Assoc UK 51:845-863

Guillard RRL, Ryther JH (1962) Studies of marine planktonic diatoms 1. Cyclotella nana Hustedt and Detonula confervacea (Cleve) Gran. Can J Microbiol 8:229-239

Langston WJ, Bebianno MJ, Burt GR (1998) Metal handling strategies in molluscs. In: Langston WJ, Bebianno M (eds) Metal metabolism in aquatic environments. Chapman \& Hall, London, p 219-283

Luoma SN (1977) Detection of trace contaminant effects in aquatic ecosystems. J Fish Res Board Can 34:436-439

Mason AZ, Jenkins KD (1995) Metal detoxification in aquatic organisms. In: Tessier A, Turner DR (eds) Metal speciation and bioavailability in aquatic systems. John Wiley \& Sons, Chichester, p 479-608

Nassiri Y, Rainbow PS, Amiard-Triquet C, Rainglet F, Smith BD (2000) Trace metal detoxification in the ventral caeca of Orchestia gammarellus (Crustacea: Amphipoda). Mar Biol 136:477-484

Phillips DJH, Rainbow PS (1988) Barnacles and mussels as biomonitors of trace elements: a comparative study. Mar Ecol Prog Ser 49:83-93

Phillips DJH, Rainbow PS (1994) Biomonitoring of trace aquatic contaminants, 2nd edn. Chapman and Hall, London

Pullen JSH, Rainbow PS (1991) The composition of pyrophosphate heavy metal detoxification granules in barnacles. J Exp Mar Biol Ecol 150:249-266

Rainbow PS (1987) Heavy metals in barnacles. In: Southward AJ (ed) Barnacle biology. AA Balkema, Rotterdam, p 405-417

Rainbow PS (1995a) Physiology, physicochemistry and metal uptake - a crustacean perspective. Mar Pollut Bull 31: 55-59

Rainbow PS (1995b) Biomonitoring of heavy metal bioavailability in the marine environment. Mar Pollut Bull 31: 183-192

Rainbow PS (1997) Ecophysiology of trace metal uptake in crustaceans. Estuar Coastal Shelf Sci 44:169-175

Rainbow PS (1998) Phylogeny of trace metal accumulation in crustaceans. In: Langston WJ, Bebianno M (eds) Metal metabolism in aquatic environments, Chapman and Hall, London, p 285-319

Rainbow PS (2002) Trace metal concentrations in aquatic invertebrates: why and so what? Environ Pollut 120:497-507

Rainbow PS, Black WH (2002) Effects of changes in salinity and osmolality on the rate of uptake of zinc by three crabs of different ecologies. Mar Ecol Prog Ser 244:205-217

Rainbow PS, Blackmore G (2001) Barnacles as biomonitors of trace metal bioavailabilities in Hong Kong coastal waters: changes in space and time. Mar Environ Res 51:441-463.

Rainbow PS, Wang WX (2001) Comparative assimilation of $\mathrm{Cd}, \mathrm{Cr}, \mathrm{Se}$, and $\mathrm{Zn}$ by the barnacle Elminius modestus from phytoplankton and zooplankton diets. Mar Ecol Prog Ser 218:239-248

Rainbow PS, White SL (1989) Comparative strategies of heavy metal accumulation by crustaceans: zinc, copper and cadmium in a decapod, an amphipod and a barnacle. Hydrobiologia 174:245-262

Rainbow PS, White SL (1990) Comparative accumulation of cobalt by three crustaceans: a decapod, an amphipod and a barnacle. Aquat Toxicol 16:113-126

Rainbow PS, Amiard-Triquet C, Amiard JC, Smith BD, Best SL, Nassiri Y, Langston WJ (1999) Trace metal uptakerates in crustaceans (amphipods and crabs) from coastal sites in NW Europe differentially enriched with trace metals. Mar Ecol Prog Ser 183:189-203

Shi D, Blackmore G, Wang WX (2003) Effects of aqueous and dietary pre-eposure and resulting body burden on the biokinetics of silver in the green mussels, Perna viridis. Environ Sci Technol 37:936-943

Walker G (1977) 'Copper' granules in the barnacle Balanus balanoides. Mar Biol 39:343-349

Wallace WG, Lopez GR, Levinton JS (1998) Cadmium resistance in an oligochaete and its effect on cadmium trophic transfer to an omnivorous shrimp. Mar Ecol Prog Ser 172: $225-237$

Wang WX (2001) Comparison of metal uptake-rate and absorption efficiency in marine bivalves. Environ Toxicol Chem 20:1367-1373

Wang WX (2002) Interactions of trace metals and different marine food chains. Mar Ecol Prog Ser 243:295-309

Wang WX, Fisher NS (1999a) Delineating metal accumulation pathways for aquatic invertebrates. Sci Total Environ 237/238:459-472

Wang WX, Fisher NS (1999b) Assimilation efficiencies of chemical contaminants in aquatic invertebrates: a synthesis. Environ Toxicol Chem 18:2034-2045

Wang WX, Rainbow PS (2000) Dietary uptake of $\mathrm{Cd}, \mathrm{Cr}$ and $\mathrm{Zn}$ by the barnacle Balanus trigonus: influence of diet composition. Mar Ecol Prog Ser 204:159-168

Wang WX, Qiu JW, Qian PY (1999a) The trophic transfer of $\mathrm{Cd}, \mathrm{Cr}$ and $\mathrm{Se}$ in the barnacle Balanus amphitrite from planktonic food. Mar Ecol Prog Ser 187:191-201

Wang WX, Qiu JW, Qian PY (1999b) Significance of trophic transfer in predicting the high concentration of zinc in barnacles. Environ Sci Technol 33:2905-2909

White SL, Rainbow PS (1984) Regulation of zinc concentration by Palaemon elegans (Crustacea: Decapoda): zinc flux and effects of temperature, zinc concentration and moulting. Mar Ecol Prog Ser 16:135-147

Xu Y, Wang WX (2001) Individual responses of trace-element assimilation and physiological turnover by the marine copepod Calanus sinicus to changes in food quantity. Mar Ecol Prog Ser 218:227-238 